\title{
Widespread disease in Caribbean sea fans: II. Patterns of infection and tissue loss
}

\author{
I. Nagelkerken ${ }^{1, *}$, K. Buchan ${ }^{2}$, G. W. Smith ${ }^{3,4}$, K. Bonair ${ }^{5}$, P. Bush ${ }^{6}$, \\ J. Garzón-Ferreira ${ }^{7}$, L. Botero ${ }^{7}$, P. Gayle ${ }^{8}$, C. D. Harvell ${ }^{9}$, C. Heberer ${ }^{10}$, K. Kim ${ }^{9}$, \\ C. Petrovic ${ }^{11}$, L. Pors ${ }^{1}$, P. Yoshioka ${ }^{10}$
}

\begin{abstract}
Large lesions and widespread tissue loss in the sea fans Gorgonia ventalina and $G$. flabellum L. occurred throughout most of the Caribbean during 1995 and 1996. An earlier study identified the putative pathogen as a fungus in the genus Aspergillus (Smith et al. 1996). Repeated surveys showed that in the Bahamas the incidence (= \% of diseased sea fans) and virulence (= \% tissue loss per diseased colonyl of the disease increased rapidly from 1995 to 1996 . Repeated surveys in Curaçao and Saba showed little variation in incidence and virulence. Incidence of the disease was higher on larger than on smaller colonies. On sheltered or moderately exposed shallow reefs $(<12 \mathrm{~m})$, both incidence and virulence were positively correlated with water depth. The number of lesions on diseased sea fans, measured only in Curaçao, also increased with depth. These patterns may result from a decrease in wave action, which usually declines with water depth, and the consequent reduction in the swaying motion of the sea fans, thus affecting success of pathogen attachment and establishment. The sea fan predator snail Cyphoma gibbosum was more abundant on diseased than on healthy colonies but its density appears to have been too low to contribute significantly to infection and tissue loss. Algal tumors were found on both healthy and diseased colonies and showed no clear association with the disease.
\end{abstract}

KEY WORDS: Disease Fungal pathogen A Aspergillus . Tissue loss - Mortality Sea fan Gorgonia ventalina Gorgonia flabellum Cyphoma gibbosum. Algal tumors

\section{INTRODUCTION}

Shallow-water communities of western Atlantic coral reefs are characterized by relatively high diversity and abundance of gorgonian corals (Kinzie 1973). Gorgonians serve as hosts for numerous commensals, symbionts and parasites, while they also provide refuge for

·E-mail: inagelk@ibm.net reef fish (Bayer 1961). Long-term studies on gorgonian survivorship show relatively high adult colony survival rates of $92 \%$ per year (Yoshioka \& Yoshioka 1991). Major sources of mortality in gorgonians are detachment, fracture of the skeleton, and overgrowth by fouling organisms (Yoshioka \& Yoshioka 1991). Factors resulting in loss of tissue on sea fan colonies include Cyphoma spp. grazing (Birkeland \& Gregory 1975, Harvell \& Suchanek 1987), fish grazing (Lasker 1985), predation by Hermodice carunculata (Wahle 1985, 
Vreeland \& Lasker 1989), and hurricanes (Yoshioka \& Yoshioka 1987).

Diseases can also be a source of significant mortality in corals (Garrett \& Ducklow 1975, Mitchell \& Chet 1975 , Antonius 1977, 1981, Gladfelter 1982 Williams \& Bunkley-Williams 1990 Bythell \& Sheppard 1993, Coles 1994), but there are few reports of diseaserelated mortality in gorgonians and other octocorals. The cyanobacterium Phormidium corallyticum is thought to be responsible for black band disease in several gorgonians (Antonius 1981, 1985) and for a similar disease in the gorgonians Pseudopterogorgia spp. (Feingold 1988). Morse et al. (1977. 1981) and Goldberg \& Makemson (1981) observed gorgonians with tumors containing filamentous algae associated with degradation of the skeleton. Mass mortality of sea fans was reported during the 1980s in Trinidad (Laydoo 1983), Costa Rica (Guzmán \& Cortés 1984), Panama (Garzón-Ferreira \& Zea 1992), Colombia (Garzón-Ferreira \& Zea 1992), and San Andrés Island (Diaz et al. 1995). The cause of these mass mortalities remains unknown.

Beginning in January 1995, lesions and necrotic tissue were observed on the sea fans Gorgonia ventalina and G. flabellum L. (Gorgoniidae). The pathogen putatively associated with the necrotic sea fan tissue was a fungus in the genus Aspergillus, a genus containing species that typically inhabit terrestrial soil (Smith et al. 1996). This fungus is suspected to infect colonies via hyphae, perhaps associated with sediment particles (Smith et al. 1996). Smith et al. (1996) showed that the disease could be spread by grafting infected tissue onto healthy tissue and also by inoculating healthy colonies with pure cultures of Aspergillus. A photograph of an infected sea fan taken during the 1980 mass mortality in Trinidad (Laydoo 1983) showed the same characteristic lesions as those on colonies infected with Aspergillus, suggesting the possibility that the earlier epidemic was also caused by the same pathogen.

Through the Caribbean Coastal Marine Productivity Network (CARICOMP 1997), qualitative and quantitative data were collected in various countries throughout the Caribbean. Nagelkerken et al. (1997) reported on the spread and signs of the disease. The objectives of the present study were to document geographic patterns of incidence and virulence, and assess ecological correlates of the disease. Incidence is defined here as the proportion of diseased individuals and virulence is defined as the tissue loss (i.e. lesion area) per colony in a given area. In addition, the presence of the sea fan predator Cyphoma gibbosum and of algal tumors (Morse et al. 1977) was quantified to examine their association with the disease.

\section{MATERIALS AND METHODS}

To determine the effects of the sea fan disease on a regional scale, institutions participating in CARICOMP were asked to collect data on infection and tissue loss in sea fans. Data were collected in the Bahamas (San Salvador), British Virgin Islands, Cayman Islands, Curaçao, Dominican Republic, Florida Keys (Key West), Jamaica, Puerto Rico, Saba and Trinidad (Fig. 1). Data were collected between August 1995 and March 1996; however, most were collected between September and November 1995. The Florida Keys data were collected during October 1996.

In each country, surveys were done at 1 to 6 sites (Table 1). All surveys were carried out in situ, using SCUBA. At each site, areas with abundant sea fans were selected and one or two 4-m-wide belt transects were placed at depths between 0.25 and $11.5 \mathrm{~m}$. The length of belt transects ranged from 12.5 to $50 \mathrm{~m}$. The mean number of sea fans surveyed per country ranged from 25 to 241 during the initial surveys (Table 1). Data 
Table 1. Number of sampling sites, variatıon in wave action and mean sea fan sample size per country wave action indices stand for: $2=1.5$ to $2.0 \mathrm{~m} ; 3=1.0$ to $1.5 \mathrm{~m} ; 4=0.5$ to $1.0 \mathrm{~m} ; 5=0.3$ to $0.5 \mathrm{~m} ; 6=0.0$ to $0.3 \mathrm{~m}$

\begin{tabular}{|c|c|c|c|c|c|c|}
\hline \multirow[t]{2}{*}{ Country } & \multirow[t]{2}{*}{ No. of sites } & \multirow[t]{2}{*}{ Wave action indices } & \multicolumn{4}{|c|}{ Mean sea fan sample size ( \pm SD) } \\
\hline & & & 1st survey & 2nd survey & 3rd survey & 4th survey \\
\hline Bahamas (San Salvador) & 5 & $4,5,6$ & $241 \pm 120$ & $.98 \pm 62$ & $117 \pm 106$ & $849 \pm 124$ \\
\hline British Virgin Islands & 4 & $3,4,5$ & $65 \pm 20$ & & & \\
\hline Cayman Islands & 2 & 2 & $25 \pm 0$ & & & \\
\hline Curaçao & 6 & 3,4 & $45 \pm 14$ & $50 \pm 0$ & & \\
\hline Dominican Republic & 1 & 6 & 100 & & & \\
\hline Florida Keys & 2 & $3-4$ & $107 \pm 42$ & & & \\
\hline Jamaica & 4 & $2-3$ & $44 \pm 19$ & & & \\
\hline Puerto Rico & 2 & $2,4-5$ & $85 \pm 69$ & & & \\
\hline Saba & 2 & 4 & $34 \pm 3$ & $35 \pm 4$ & & \\
\hline Trinidad & 1 & 4 & 25 & & & \\
\hline
\end{tabular}

Fig. 2. Gorgonia sp. Illustration of (A) small purple lesions (arrows) suspected to have developed after initial infection (scale bar = $1 \mathrm{~cm}),(B)$ advanced infection resulting in loss of both tissue and skeleton (arrows; scale bar = $20 \mathrm{~cm}$ ). See also Nagelkerken et al. (1997) for photograph of heavily infected sea fan with almost complete tissue loss

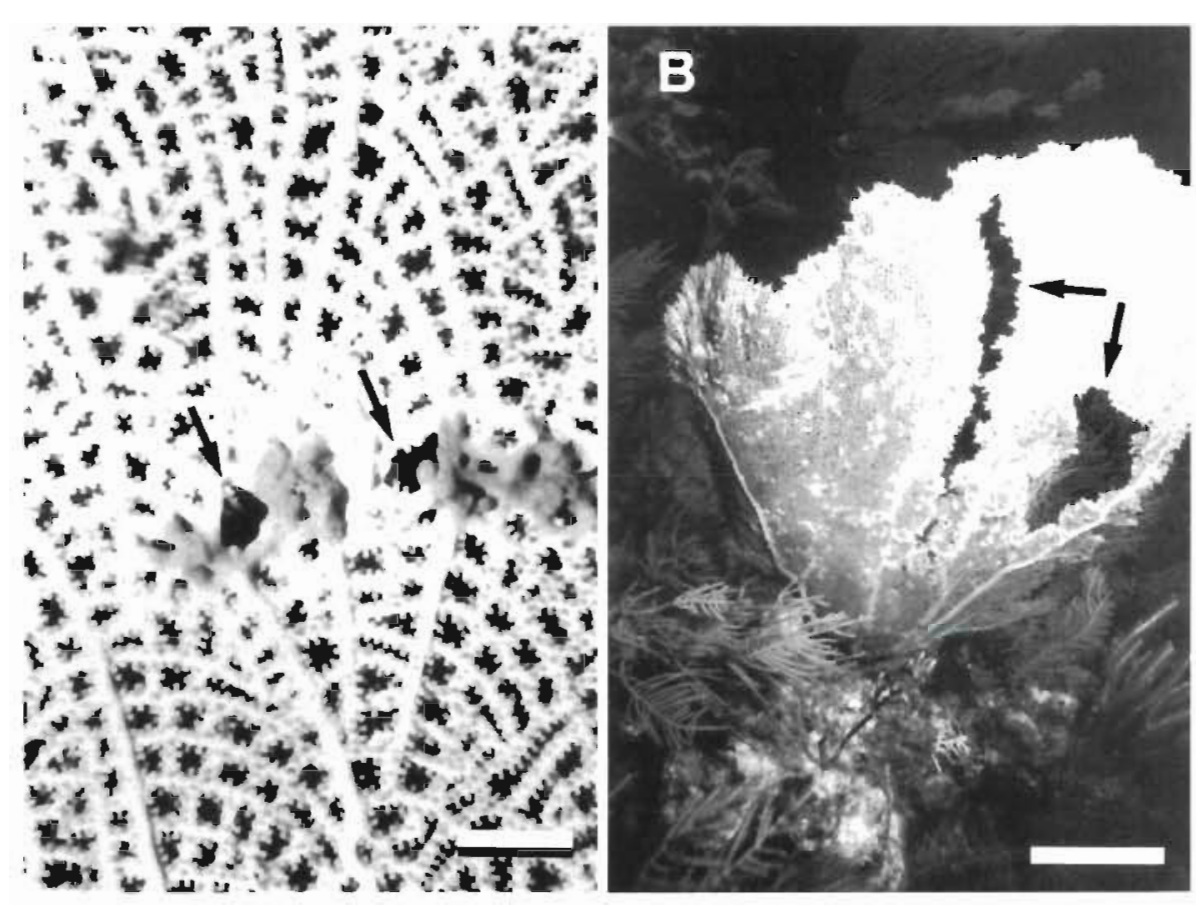

were collected for Gorgonia ventalina and G. flabellum; $G$. mariae was not encountered in the transects. At each site, mean wave height was estimated and expressed using indices of Van Duyl (1985): $1=2.0$ to $3.5 \mathrm{~m} ; 2=1.5$ to $2.0 \mathrm{~m} ; 3=1.0$ to $1.5 \mathrm{~m} ; 4=0.5$ to $1.0 \mathrm{~m}$; $5=0.3$ to $0.5 \mathrm{~m} ; 6=0.0$ to $0.3 \mathrm{~m}$.

Diseased sea fans were identified as those with lesions or necrotic tissue (Fig. 2). Lesions resulting from the disease were unlike lesions caused by other agents such as Cyphoma spp., Hermodice carunculata. and fish grazing, and wave and hurricane damage. Diseased colonies have irregular lesions of various sizes distributed throughout the sea fan blade (Nagelkerken et al. 1997). Both tissue and skeleton disappear as a result of the disease, and the necrotic tissue along the edges of the lesions is generally lighter in color than the healthy sea fan tissue (Nagelkerken et al. 1997). In some regions such as the Bahamas and the Florida Keys, diseased tissue is dark purple in contrast to the lighter coloration of healthy tissue. The presence of Aspergillus in infected tissue was confirmed in samples collected in the Bahamas, the British Virgin Islands, Curaçao, Florida Keys, Saba and Trinidad (Smith et al. 1996). Thus, although we are certain that the fungus was present in most study locales, because of the many sites and colonies surveyed, it was not possible to confirm that every colony diagnosed in the field as diseased was indeed infected with the fungal pathogen.

On each transect, the number of healthy and diseased colonies (i.e. incidence) was determined. Each sea fan was carefully examined for disease-related 
lesions or necrotic tissue. The smallest lesions used to diagnose colonies as diseased were 3 to $5 \mathrm{~cm}^{2}$, but this was only the case for a few colonies in Jamaica and the Cayman Islands. Most colonies had multiple lesions larger than approximately $50 \mathrm{~cm}^{2}$. To determine disease virulence, the percent of a colony surface area consisting of lesions was measured using a square PVC frame divided with string into $10 \mathrm{~cm}^{2}$ grids. For each sea fan the maximum colony height was recorded. In Curaçao, the number of lesions on diseased colonies was also counted.

To study changes in incidence and virulence over time, surveys were repeated in single transects for a total of 8 different sites in 3 countries. The surveys were repeated at 4 of the 5 sites in the Bahamas during July 1995, December 1995, July 1996, and December 1996, at 2 sites in Curaçao during November 1995 and June 1996, and at 2 sites in Saba during August 1995 and June 1996. Changes in incidence and virulence were tested using a 1-way ANOVA with time as the independent variable and sites as replicates. When appropriate, these data were arcsin-transformed (Sokal \& Rohlf 1995) prior to analysis. During the repeated surveys in July 1996, sea fans were separated to species level in the Bahamas to study differences in susceptibility of disease. The incidence and virulence for each species were determined in a single transect at 5 different sites. Species differences were tested using paired $t$-tests with sites as replicates.

In some countries, the presence and the numbers of algal tumors (Morse et al. 1977) and of the sea fan predator Cyphoma gibbosum were determined for each sea fan.

\section{RESULTS}

\section{Progress of disease}

Repeated surveys in the Bahamas showed an increase in the incidence of disease with time (Fig. 3a). By December 1996, approximately $60 \%$ of all sea fans were affected, averaging a 3 -fold increase from the start of the survey, with much of the increase occurring during the 2 latter surveys. The significance of this increase was noted in a 1-way ANOVA with time as the dependent variable and sites as replicates $\left(F_{3,10}=\right.$ $11.3, \mathrm{p}=0.0015)$. Virulence also varied over time $\left(F_{3,10}=6.15, \mathrm{p}=0.0122\right)$, although not monotonically, and increased only between the December 1995 and July 1996 surveys (Fig. 3b).

At 2 sites in Curaçao, surveys carried out in November 1995 and June 1996 showed little change in either incidence (mean: 39 vs $32 \%$ ) or virulence (mean: 6 vs $5 \%$ ) over time. Similarly, disease states at 2 Saba sites
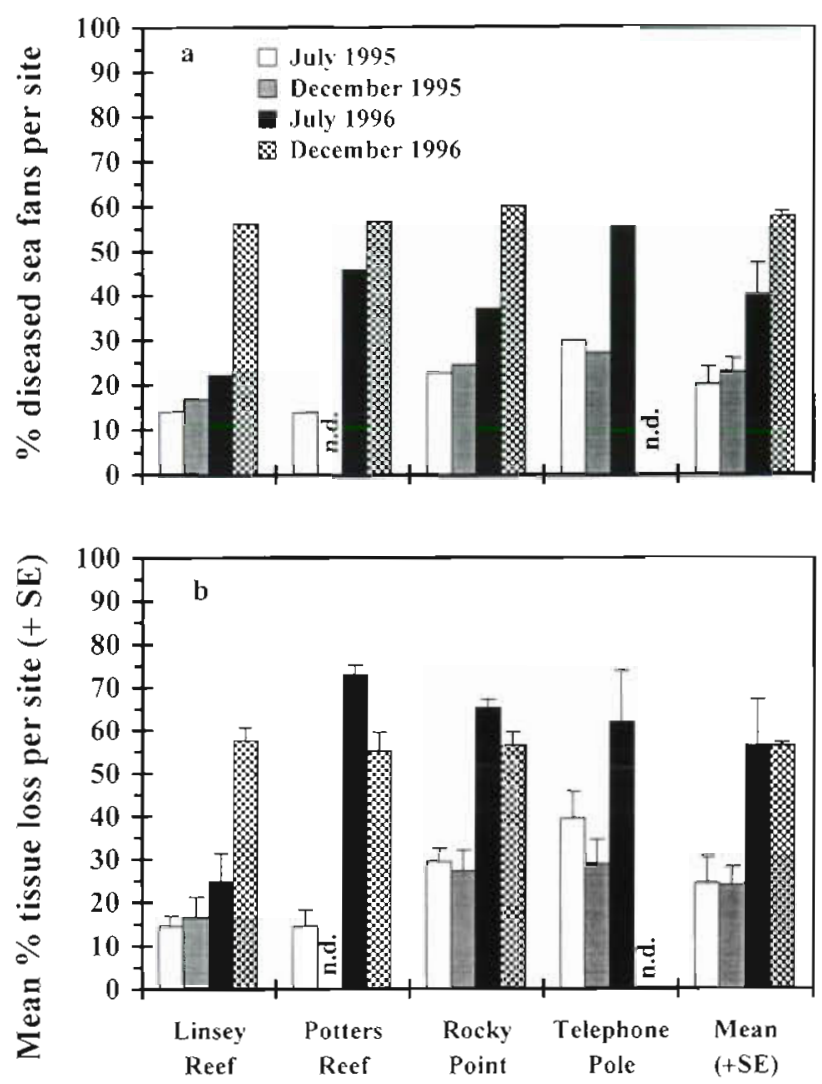

Fig. 3. Gorgonia spp. (a) Incidence and (b) virulence of disease for repeated surveys at 4 sites in the Bahamas. n.d.: no data

remained relatively unchanged over August 1995 and June 1996 survey periods: incidence, 90 vs $94 \%$; virulence, 45 vs $52 \%$.

\section{Susceptibility of Gorgonia ventalina and G. flabellum}

In the Bahamas, both Gorgonia ventalina and G. flabellum were infected with the disease. Both the incidence and virulcnce were higher in $G$. ventalina than G. flabellum at 4 of the 5 sites (Fig. 4). However, this trend was not resolved using paired $t$-tests with the 5 sites as replicates (incidence: $t=1.595, \mathrm{df}=4, \mathrm{p}=$ 0.1860 ; virulence: $t=1.594, \mathrm{df}=4, \mathrm{p}=0.1861$ ).

\section{Correlations of disease with water depth and colony size}

The incidence of disease was independent of colony density but increased with water depth on the shallow $(<12 \mathrm{~m})$ reefs. As shown in Fig 5, disease incidence 

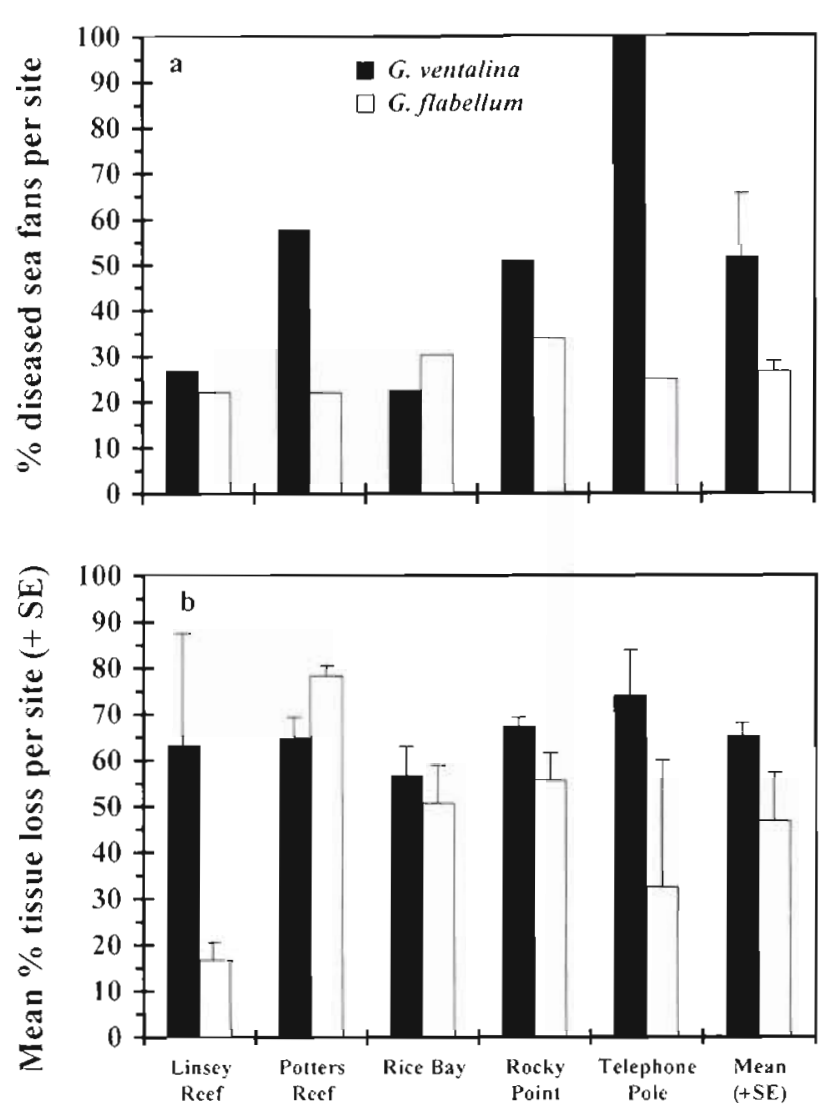

Fig. 4. (a) Incidence and (b) virulence of disease for Gorgonia flabellum and $G$. ventalina at 5 sites in the Bahamas

also tended to decrease with wave exposure. At sites with low to moderate wave action (= protected, index 3 to 6 , see Table 1), incidence increased linearly with depth ( $p<0.001$, linear regression). In contrast, at sites with high wave action (= exposed, index 2 to 3 , Table 1) such as in the Cayman Islands, Jamaica and Puerto Rico, incidence was lower than predicted by the regression line Most notable is the comparatively low incidence of $11.9 \%$ recorded at a protected site (depth $=8.5 \mathrm{~m}$ ) in Puerto Rico.

The virulence of disease was also correlated with water depth on the shallow reef, but showed a somewhat different pattern compared to that of incidence (Fig. 6). At least 3 separate patterns can be made out from the available data. Firstly, a significant increase with depth was found in Curaçao. Data from deeper sites in the British Virgin Islands, Trinidad and Saba also show this pattern, and the overall increase with depth in these countries was highly significant ( $\mathrm{p}<$ 0.001 , linear regression on log-transformed data). Data collected from a site in Saba (11.5 m) and one in Puerto Rico ( $8.5 \mathrm{~m}$ ) deviated from this trend (Fig. 6). Secondly, similar to low incidences at exposed sites (see Figs. $5 \&$ 7 ), virulence was much lower at the exposed sites in the Cayman Islands and Jamaica (Fig. 6). Lastly, values for protected sites in the Bahamas were much higher than predicted by the regression line, although they tended to increase with water depth (Fig. 6).

The incidence of disease increased with sea fan size on the shallow reef (Fig 7). However, no relationship was present between virulence and sea fan size. These results are based on data from 4 countries (out of 10), where sea fan sizes were measured. Virulence at exposed sites for a depth range of 8 to $10 \mathrm{~m}$ were much lower than expected, and were consistent with the observations from Fig. 5. Some of the variation around the regression line in Fig. 5 may thus have been caused by differences in sea fan size at the various sites. The mean number of lesions per colony, measured only in Curaçao, also increased with depth on the shallow reef $\left(r^{2}=0.80, p=0.016\right.$, linear regression; Table 2).

\section{Cyphoma gibbosum}

The snail Cyphoma gibbosum was observed on sea fans during the course of the surveys. Although the

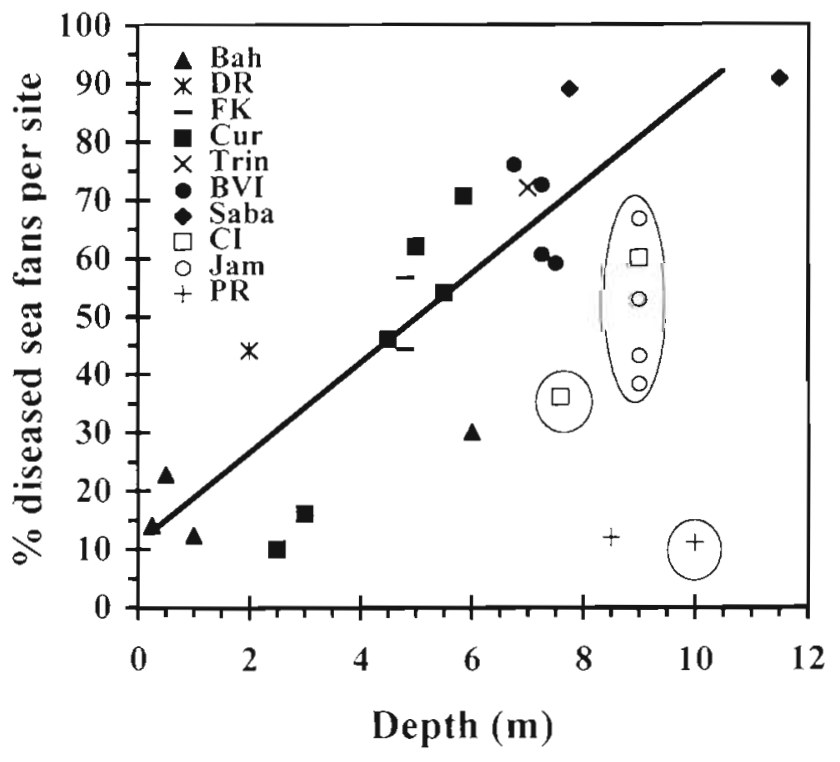

Fig. 5. Gorgonia spp. Incidence of disease as a function of water depth, showing the fitted regression line for sites with a low to moderate wave action $\left(\mathrm{r}^{2}=0.77, \mathrm{p}<0.001\right.$, excluding deviating value at $8.5 \mathrm{~m}$ depth in Puerto Rico; $\mathrm{r}^{2}=0.52, \mathrm{p}<$ 0.001 , including deviating value). Data from the Florida Keys were not included in the analyses as they were collected 1 yr later Sites with relatively high wave action, viz. Jamaica (index between 2 and 3 ) and the Cayman Islands and Puerto Rico (index 2), are circled. Bah $=$ Bahamas, $D R=$ Dominican Republic, FK = Florida Keys, Cur = Curaçao, Trin = Trinidad, $\mathrm{BVI}=$ British Virgin Islands, $\mathrm{CI}=$ Cayman Islands; $\mathrm{Jam}=$ Jamaica; PR = Puerto Rico 


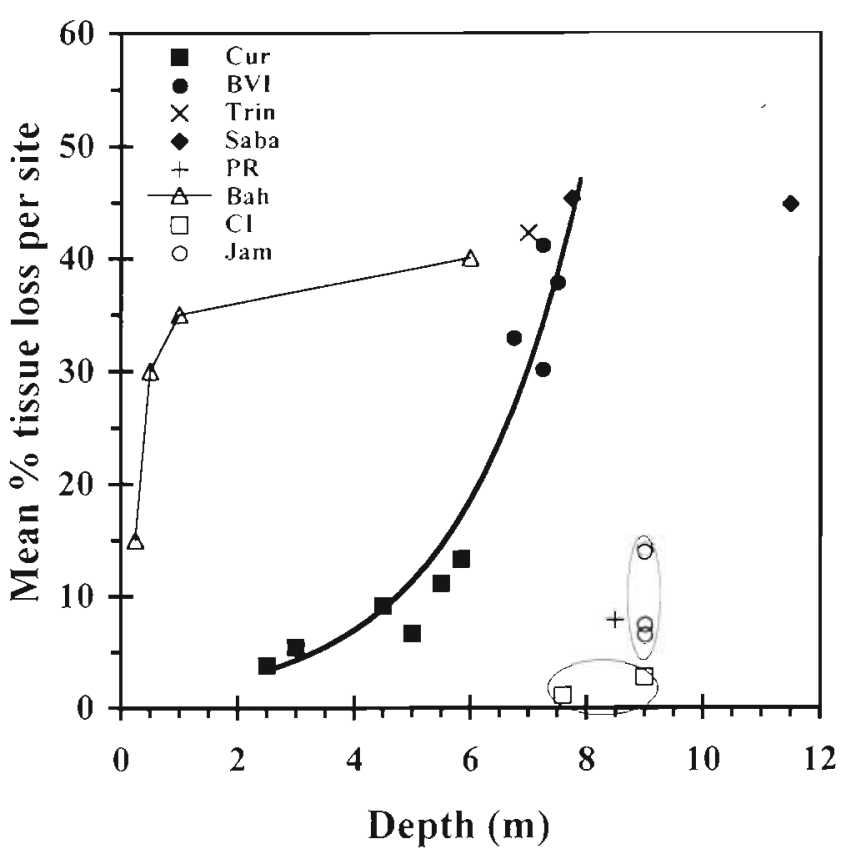

Fig. 6. Gorgonia spp. Virulence of disease as a function of water depth showing the fitted regression line for sites in the British Virgin Islands, Curaçao, Saba, and Trinidad with low to moderate wave action $\left(r^{2}=0.92, p<0.001\right.$, excluding deviating values at $11.5 \mathrm{~m}$ in Saba and $8.5 \mathrm{~m}$ in Puerto Rico; $\mathrm{r}^{2}=0.52, \mathrm{p}=$ 0.004 , including all values). Sites with relatively high wave action, viz. Jamaica (index between 2 and 3 ) and the Cayman Islands (index 2), are circled. Abbreviations as in Fig. 5

snails were relatively rare, the majority of those abserved were on diseased fans (Table 3). The abundance of $C$. gibbosum was significantly higher on diseased sea fans than on healthy sea fans in both the British Virgin Islands and Jamaica but not in Curaçao (Table 3). However, we found only 5 to $24 \%$ of all diseased sea fans with 1 or more (maximum $=3$ ) predatory snails.

\section{Algal tumors}

In Curaçao, $44.1 \%$ of 150 sea fans surveyed had algal tumors. These algal tumors were found on both healthy and diseased colonies in equal proportions $\left(\chi_{1}{ }^{2}\right.$ $=0.63, p>0.05$, chi-square test). The percentage of both healthy and diseased sea fans carrying algal tumors in Curaçao increased with sea fan size (Table 4), although not with water depth. In the Florida Keys, algal tumors were more often associated with healthy sea fans $\left(\chi_{1}^{2}=4.72, p<0.05\right)$. At all. 3 sites in the Bahamas, the proportion of sea fans with algal tumors was higher among Gorgonia ventalina than $G$. flabellum (Fig. 8); however, the difference was not resolved statistically due to the limited sample size.

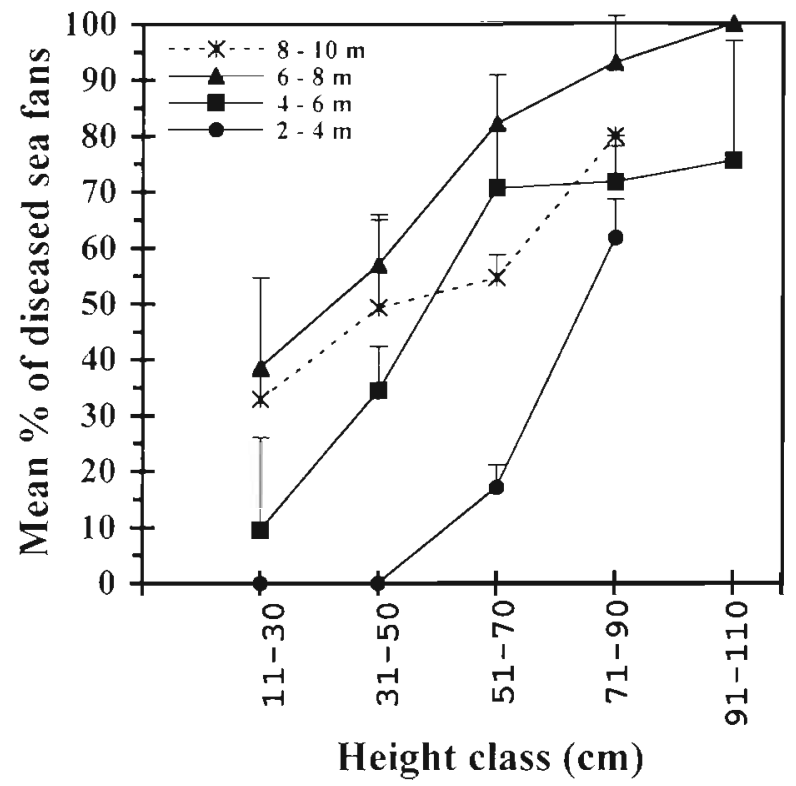

Fig. 7. Gorgonia spp. Percentage of diseased sea fans (mean + SD) as a function of colony height at various depths. Data are from sites shown in Fig. 5, and have been pooled as follows: 2 to $4 \mathrm{~m}$, Curaçao ( $\mathrm{N}=2$ sites); 4 to $6 \mathrm{~m}$, Curaçao ( $\mathrm{N}=4$ sites); 6 to $8 \mathrm{~m}$, British Virgin Islands ( $N=4$ sites); and 8 to $10 \mathrm{~m}$, Jamaica ( $N=3$ sites). Solid lines represent sites with low to moderate wave exposure, while the dotted line represents sites with high exposure

Table 2. Mean number of lesions on diseased sea fans ( $N$ ) at different sites and various depths in Curaçao. "One sea fan with 87 lesions was excluded to avoid skewing of the mean

\begin{tabular}{|lccr|}
\hline Location & $\begin{array}{c}\text { Depth } \\
(\mathrm{m})\end{array}$ & $\begin{array}{c}\text { Mean no. of } \\
\text { lesions }( \pm \mathrm{SD})\end{array}$ & $\mathrm{N}$ \\
\hline Kaap Malmeeuw & 2.5 & $2.6 \pm 1.1$ & 5 \\
Boca di Sorsaka & 3.0 & $2.0 \pm 0.8$ & 8 \\
Boei 2 & 4.5 & $3.4 \pm 2.6$ & 23 \\
Punt'i Pikú & 5.0 & $5.7 \pm 4.8$ & 31 \\
Barank'i Karañito & 5.5 & $8.4 \pm 9.5$ & 27 \\
Rif St. Marie & 5.9 & $7.1 \pm 6.8$ & 12 \\
\hline
\end{tabular}

\section{DISCUSSION}

As documented in our surveys, the epizootic affecting the sea fans Gorgonia ventalina and G. flabellum is widespread throughout the Caribbean. Our data so far suggest that there are no species differences in either incidence or virulence. Although more extensive monitoring and longer intervals are necessary to fully assess the temporal dynamics of the disease, data from the Bahamas sites indicate that incidence is on the increase whereas virulence has apparently peaked. At 
Table 3. Occurrence of Cyphoma gibbosum snails on sea fans Gorgonia spp. in 4 different countries. Sample sizes of $C$. gibbosum and of diseased sea fans, respectively, are given in parentheses. $\chi^{2}$ shows chi-square test statistics (2-way classification) for comparison between no. of $C$ gibbosum on healthy and on diseased sea fans. 'Significant $(p<0.05)$, " highly significant $(p<0.01)$. na $=$ not applicable

\begin{tabular}{|lcccc|}
\cline { 2 - 5 } & $\begin{array}{c}\text { British Virgin } \\
\text { Islands }\end{array}$ & Cayman Islands & Curaçao & Jamaica \\
\hline $\begin{array}{l}\text { No. of sites } \\
\% \text { of total no. of } \\
\begin{array}{l}\text { C. gibbosum found } \\
\text { on diseased sea fans }\end{array}\end{array}$ & $100(11)$ & na (0) & $63(16)$ & $96(25)$ \\
$\chi^{2}$ & $4.5^{\circ}$ & & & \\
$\begin{array}{l}\% \text { of total no. of } \\
\text { diseased sea fans } \\
\text { carrying C. gibbosum }\end{array}$ & $5.3(170)$ & $0.0(24)$ & $10.2(59)$ & $23.9(71)$ \\
\hline
\end{tabular}

The disease incidence, virulence, and mean number of lesions per colony (in Curaçao) increased with depth at sites with low to moderate wave action, and the incidence and virulence were greater at protected sites than exposed sites. Wahle (1985) documented an increase in the percentage of gorgonians encrusted by fouling organisms and the mean number of fouling organisms per colony when moving from exposed to protected reef zones. One hypothesis is that a reduction in the swaying motion of sea fans at more protected sites and at greater depths facilitates attachment and establishment of pathogens such as Aspergillus, result-

Table 4. Percentage of diseased and healthy sea fans affected with algal tumors, for various height classes in Curaçao $(\mathrm{N}=3$ sites). Sample size of sea fans is given in parentheses. -: no data

\begin{tabular}{|lrr|}
\hline $\begin{array}{l}\text { Height class } \\
(\mathrm{cm})\end{array}$ & $\begin{array}{c}\% \text { of sea fans affected with tumors } \\
\text { Diseased }\end{array}$ & $\begin{array}{c}\text { Healthy } \\
11-30\end{array}$ \\
\hline $31-50$ & $-(0)$ & $3.6(28)$ \\
$51-70$ & $16.7(6)$ & $3.3(30)$ \\
$71-90$ & $37.5(6)$ & $13.3(15)$ \\
$91-110$ & $34.8(23)$ & $27.3(11)$ \\
& $70.0(10)$ & $-(0)$ \\
\hline
\end{tabular}

2 of the sites, virulence appears to be decreasing, suggesting some degree of tissue recovery in affected sea fans. At sites in 2 other countries (Saba and Curaçao) where surveys were done on a more limited scale, disease incidence and virulence appear to remain unchanged.

Previous studies of sea fan mass mortalities reported almost complete decimation of sea fan populations (Laydoo 1983, Guzmán \& Cortés 1984, Garzón-Ferreira \& Zea 1992). Laydoo (1983) found that tissue loss in Gorgonia ventalina ranged from 2 to $25 \%$ of the sea fan per week, and noted the demise of a sea fan community within half a year in Macqueripe Bay on the north coast of Trinidad. Guzmán \& Cortés (1984) reported that in Costa Rica more than $90 \%$ of the sea fans had died within 1 yr. In Santa Marta, Colombia, sea fans showed almost complete mortality after 1 to 1.5 yr (Garzón-Ferreira \& Zea 1992). However, in the current epizootic, no instances of complete tissue loss (i.e. colony death) have yet been documented since the first observation of the disease in January 1995. This suggests that in spite of the wider spread of the disease (Nagelkerken et al. 1997), virulence of this epizootic is lower than in 1980. ing in higher infection rates and consequent tissue loss. Sea fan size was positively correlated with disease incidence, but not with virulence or number of lesions per infected colony. There was a trend towards higher incidence of algal tumors in Gorgonia ventalina, suggesting that this species is more susceptible to certain types of infection than $G$. flabellum

Most Cyphoma gibbosum were found on diseased sea fans. Tissue predation by this snail can expose the internal skeleton of the sea fan and can thus facilitate colonization by fouling organisms (Wahle 1985, Gerhart 1990) as well as pathogens. However, Smith et al. (1996) showed in aquarium experiments that the disease could be transmitted to healthy sea fans without the presence of $C$. gibbosum scars. Harvell \& Suchanek (1987) observed that most $C$. gibbosum scars were located in the central region of sea fan colonies, in contrast to the distribution of lesions throughout the

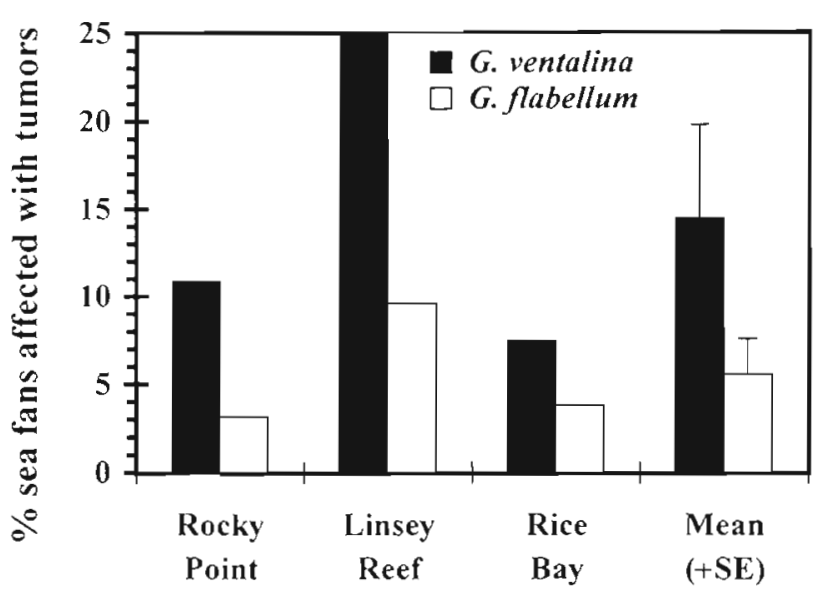

Fig. 8. Percentage of Gorgonia ventalina and $G$. flabellum colonies infected with algal tumors at several sites in the Bahamas 
sea fan blade and even at colony edges found in the present study. Furthermore, the snails were relatively rare (Table 3) and were found on only 0 to $24 \%$ of the diseased colonies. Thus, scars resulting from C. gibbosum grazing are not thought to have played a significant role in facilitating attachment of the pathogen.

The number of algal tumors (Morse et al. 1977) increased with fan size but not with water depth, as was observed for the incidence and virulence of the disease. Also, no significant association was found between the presence of algal tumors and lesions on sea fans. Thus, the presence of algal tumors may be unrelated to the disease of the sea fans. Observations by Goldberg \& Makemson (1981) on the occurrence of tumors in the gorgonians Pseudoplexaura spp. agree with our results, in that larger colonies were more likely to have tumors but the number of tumors did not increase with colony size. They argue that algal infection is dependent on colony age (i.e. size) whereas the number of tumors is dependent on the spreading of algal filaments after the initial infection rather than on multiple infections. Our observations on the wide spatial occurrence of algal tumors differ from those of Morse et al. (1981) who found tumor-bearing sea fans to be highly localized and occurring in just one area in Bonaire and Trinidad. In our surveys tumor-bearing sea fans occurred at almost all sites in countries where their occurrence was recorded.

Acknowledgements. In Curaçao, work was funded by the Island Government of Curaçao and the Central Government of the Netherlands Antilles, by their annual subsidy to the Carmabi Foundation and the Curaçao Underwater Park. In Saba, work was funded by the Saba Marine Park. We are grateful for the excellent cooperation of the CARICOMP network, without whose help this study would not have been possible. We are indebted to Drs J Woodley and J. Ogden for attending to the communications within the CARICOMP network and their all-around suggestions. Logistic support was provided by M. Carlo in Puerto Rico, by K. Fedorka and A. Downes in Jamaica, by C. Quirolo of Reef Relief in Florida, and by D. Shapiro in Mexico. The manuscript benefited from the comments and suggestions of 4 anonymous reviewers.

\section{LITERATURE CITED}

Antonius A (1977) Coral mortality in reefs: a problem for scjence and management. Proc 3rd Int Coral Reef Symp 2: $618-623$

Antonius A. (1981) The 'band' diseases in coral reefs. Proc 4th Int Coral Reef Symp 2:7-14

Antonius A (1985) Black band disease infection experiments on hexacorals and octocorals. Proc 5th Int Coral Reef Symp 6:155-160

Bayer FM (1961) The shallow-water Octocorallia of the West Indian region. Stud Fauna Curaçao Other Caribb Isl 55

Birkeland C. Gregory B (1975) Foraging behaviour and rates of feeding of the gastropod, Cyphoma gibbosum. Bull Nat Hist Mus Los Angeles Co 20:57-67
Bythell J, Sheppard C (1993) Mass mortality of Caribbean shallow corals. Mar Pollut Bull 26:296-297

CARICOMP (1997) Caribbean coastal marine productivity: a research and monitoring network of marine laboratories, parks, and reserves. Proc 8th Int Coral Reef Symp 1. $657-662$

Coles SL (1994) Extensive coral disease outbreak at Fahl Island, Gulf of Oman. Indian Ocean. Coral Reefs 13: 242

Diaz JM, Garzon-Ferreira J, Zea S (1995) Los arrecifes coralinos de la isla de San Andres, Colombia: estado actual y perspectivas para su conservacion. Academia Colombiana de Ciencias Exactas, Físicas y Naturales, Coleccion Jorge Alvarez Lleras No. 7, Santafé de Bogotá, DC

Feingold JS (1988) Ecological studies of a cyanobacterial infection on the Caribbean sea plume Pseudopterogorgia acerosa (Coelenterata: Octocorallia). Proc 6th Int Coral Reef Symp 3:157-162

Garrett P, Ducklow H (1975) Coral diseases in Bermuda. Nature 253:349-350

Garzón-Ferreira J, Zea S (1992) A mass mortality of Gorgonia ventalina (Cnidaria: Gorgoniidae) in the Santa Marta area, Caribbean coast of Colombia. Bull Mar Sci 50: $522-526$

Gerhart DJ (1990) Fouling and gastropod predation: consequences of grazing for a tropical octocoral. Mar Ecol Prog Ser 62:103-108

Gladfelter WB (1982) White-band disease in Acropora palmata: implications for the structure and growth of shallow reefs. Bull Mar Sci 32:639-643

Goldberg WM, Makemson JC (1981) Description of a tumorous condition in a gorgonian coral associated with a filamentous green alga. Proc 4th Int Coral Reef Symp 2: $685-697$

Guzmán HM, Cortés J (1984) Mortandad de Gorgonia flabellum Linnaeus (Octocorallia: Gorgoniidae) en la Costa Caribe de Costa Rica. Rev Biol Trop 32:305-308

Harvell CD, Suchanek TH (1987) Partial predation on tropical gorgonians by Cyphoma gibbosum (Gastropoda). Mar Ecol Prog Ser 38:37-44

Kinzie RA (1973) The zonation of West Indian gorgonians. Bull Mar Sci 23:93-1,55

Lasker HR (1985) Prey preferences and browsing pressure of the butterflyfish Chaetodon capistratus on Caribbean gorgonians. Mar Ecol Prog Ser 21:213-220

Laydoo R (1983) Recent mass mortality of gorgonians in Trinidad. Unpubl report. Institute of Marine Affairs. Trinidad

Mitchell R, Chet I (1975) Bacterial attack of corals in polluted seawater. Microb Ecol 2:227-233

Morse DE, Morse ANC, Duncan H (1977) Algal tumors in the Caribbean sea-fan, Gorgonia ventalina. Proc 3rd Int Coral Reef Symp 1:623-629

Morse DE, Morse A, Duncan H, Trench RK (1981) Algal 'tumors' in the Caribbean octocorallian, Gorgonia ventalina: II. Biochemical characterization of the algae, and first epidemiological observations. Bull Mar Sci 31 $399-409$

Nagelkerken I, Buchan $K$, Smith GW, Bonair K, Bush P, Garzón-Ferreira J, Botero L, Gayle P, Heberer C, Petrovic C, Pors L, Yoshioka P (1997) Widespread disease in Caribbean sea fans: I. Spreading and general characteristics. Proc 8th Int Coral Reef Symp 1:679-682

Smith GW, Ives LD, Nagelkerken IA, Ritchie KB (1996) Caribbean sea fan mortalities. Nature 383:487

Sokal RR, Rohlf FJ (1995) Biometry, 3rd edn. WH Freeman and Company, New York 
Van Duyl FC (1985) Atlas of the living reefs of Curaçao and Bonaire (Netherlands Antilles). Foundation for scientific research in Surinam and the Netherlands Antilles, Utrecht

Vreeland AL, Lasker HR (1989) Selective feeding of the polychaete $H$. carunculata (Pallas) on Caribbean gorgonians J Exp Mar Biol Ecol 129:265-277

Wahle CM (1985) Habitat-related patterns of injury and mortality among Jamaican gorgonians. Bull Mar Sc1 $37: 905-927$

Editorial responsibility: Otto Kinne (Editor). Oldendorf/Luhe, Germany
Williams EH, Bunkley-Williams L (1990) The world-wide coral reef bleaching cycle and related sources of coral mortality. Atoll Res Bull 335:1-71

Yoshioka PM, Yoshioka BB (1987) Variable effects of hurricane David on the shallow water gorgomans of Puerto Rico. Bull Mar Sci 40:132-144

Yoshioka PM, Yoshioka BB (1991) A comparison of the survivorship and growth of shallow-water gorgonian species of Puerto Rico. Mar Ecol Prog Ser 69:253-260

Submitted: March 25, 1997; Accepted: October 15, 1997 Proofs received from author(s): December 9, 1997 